\title{
IAMJ
}

INTERNATIONAL

AYURVEDIC

MEDICAL JOURNAL

Review Article

ISSN: 2320-5091

Impact Factor: 6.719

\section{A REVIEW ARTICLE ON THE PHYSIOLOGICAL IMPORTANCE OF SAMANA VAYU IN RELATION TO THE ENTERIC NERVOUS SYSTEM}

\author{
Neha Sajwan', Rajesh Kumar Sharma², Dinesh Chandra Sharma ${ }^{3}$ \\ ${ }^{1}$ P.G. Scholar, P.G department of Kriya Sharir, DSRRAU, Jodhpur, Rajasthan, India \\ ${ }^{2}$ Professor and H.O.D., P.G. Department of Kriya Sharir, DSRRAU, Jodhpur, Rajasthan, India \\ ${ }^{3}$ Associate Professor, P.G. Department of Kriya Sharir, DSRRAU, Jodhpur, Rajasthan, India
}

Corresponding Author: sajwanneha23@gmail.com

\section{https://doi.org/10.46607/iamj3009122021}

(Published Online: December 2021)

Open Access

(C) International Ayurvedic Medical Journal, India

Article Received: 29/11//2021 - Peer Reviewed: 10/12/2021 - Accepted for Publication 11/12/2021

\section{Check for updates}

\begin{abstract}
Ayurveda is a science that has been around for thousands of years and has proven to be beneficial to humans. Ayurveda is based on the tridosha theory. Vata, one of three doshas, plays an essential and major part in both healthy and unhealthy conditions, according to acharya sushruta dosha, dhatu and mala maintain our body. There are five types of vata- prana, udan, samana, vyan and apaan vayu. Among these five doshas samana vayu is situated near jatharagni and circulate all over the GIT tract. It helps in the division of essence and waste products, as well as the movement of the gastrointestinal tract, by stimulating the agni. In the body, jatharagni takes the form of pachak pitta, one of the pitta subtypes. Agnimandhya is responsible for all diseases, as we all know. The fire is fueled by samana vayu, who keeps it balanced. As a result, samana vayu might be regarded to play a specialized role in digestion. All of the samana vayu's functions can be compared to the physiological functions of the enteric nervous system and the sympathetic and parasympathetic supply of the Autonomic nervous system to the gastrointestinal tract. In this article, an attempt is made to correlate the physiological activity of samana vayu with the enteric nervous system.
\end{abstract}

Keywords: Samana vayu, Prana vayu, Apan vayu, Sacral Segment. 


\section{INTRODUCTION}

Health, according to Ayurveda, is a state in which the dosha, agni, dhatus, waste products, and all physiological systems are in a homeostatic state, and the soul, sense organs, and mind are in a state of absolute wellbeing (1). Vata, in its natural state, causes all of our body's organs to work properly. As a result, it is known as Yantra dhara. It is regarded as the Prana (LIFE) of all people. Vata dosha performs a variety of activities, including maintaining the function of organs and organ systems in their natural state. Vata is the human body's initiating and governing element, as well as the cause of all types of movements ${ }^{(2)}$. All cerebral functions are controlled and impelled by Vata, while all sensory abilities are employed by Vata.
According to Acharya Sushruta Samana vayu is situated in swedvaha srotas, doshavaha srotas and ambuvaha srotas and gives strength to agni (digestive fire)

Samana vayu, one of the five varieties of vata, performs a variety of activities at various levels. Prana vayu, vyana vayu, and apana vayu are also used to carry out their functions. When executing physiological activities, this vayus should collaborate and coordinate with one another. As a result, in a modern perspective, a thorough comprehension of the functions is required. Because Ayurveda is a discipline built on the concept of functional understanding, it cannot be fully represented by a single organism at any given time.

Table 1: Site and Functions of Samana Vayu by Different Acharya:

\begin{tabular}{|c|c|c|c|c|}
\hline & Charak samhita ${ }^{(3)}$ & Sushrut samhita ${ }^{(4)}$ & Astang hrudaya ${ }^{(5)}$ & Astang samgraha ${ }^{(6)}$ \\
\hline sthan & $\begin{array}{l}\text { Present in perspira- } \\
\text { tion, humour, and } \\
\text { water channels, as } \\
\text { well as on the lat- } \\
\text { eral side of the } a g \text { - } \\
n i \text { 's seat. }\end{array}$ & $\begin{array}{l}\text { It moves in the } \\
\text { aamashaya and pak- } \\
\text { vashaya associating } \\
\text { with agni }\end{array}$ & $\begin{array}{l}\text { Present near jatharagni } \\
\text { and travels throughout } \\
\text { the koshtha }\end{array}$ & $\begin{array}{l}\text { Present near the digestive fire, it passes } \\
\text { via the large intestine, stomach, and } \\
\text { small intestine, as well as the dosha } \\
\text { channels, malas (waste), sukra (male re- } \\
\text { productive tissue), artava (menstrual } \\
\text { fluid), and ovum (female reproductive } \\
\text { tissue), and ambu (body fluid) }\end{array}$ \\
\hline karma & $\begin{array}{l}\text { Give up the } \\
\text { strength to the } \\
\text { agni. }\end{array}$ & $\begin{array}{l}\text { It breaks down the } \\
\text { food and separates the } \\
\text { end product (essence } \\
\text { and waste of food af- } \\
\text { ter digestion). }\end{array}$ & $\begin{array}{l}\text { It takes food into the di- } \\
\text { gestive tract, digests it, } \\
\text { separates the essence } \\
\text { from the excrement, } \\
\text { and releases it into the } \\
\text { appropriate pathways. }\end{array}$ & $\begin{array}{l}\text { Kindle a fire in the stomach. Support the } \\
\text { srotas in their duties, such as food reten- } \\
\text { tion in the alimentary tract, digestion, es- } \\
\text { sence and waste separation, and waste } \\
\text { product movement downwards. }\end{array}$ \\
\hline
\end{tabular}

\section{MODERN VIEW -}

1) ANNAM GRUHNATI - It refers to the act of receiving and withholding food in the gastrointestinal tract. Prana vayu's function is Anna grahan. Food is then moved from the stomach to the small intestine by the action of samana vayu and ultimately excreted throughout the body by apan vayu. The mechanism of deglutition is complex. In a current context, we can compare this mechanism to the following-

\section{Deglutition}

$>$ Upper oesophagal sphincter opening

$>$ lower oesophagal sphincter opening

These peristaltic waves are initiated and controlled by intrinsic neuronal Circuits in the mesenteric nervous System ${ }^{(7)}$. All of these mechanisms Are the result of prana vayu. food reaches in stomach

\section{Stomach to the small intestine}

\section{Hunger contraction}


Receptive relaxation

Peristalsis movement

\section{Small intestine to large intestine}

Mass peristalsis

Segmentation movement

Defecation

\section{- All of these mechanisms are the Result of samana vayu}

2) ANNAM PACHATI - Samana vayu stimulates pachak pitta hence samana vayu and pachak pitta both act as agni (digestive fire). When Samana vayu stimulates pitta digestion process happened, according to modern science digestion occur due to digestive enzymes. samana vayu increase the secretion of active enzymes and inactive enzymes also became active.

The agni, which is responsible for digestion and metabolism, is stimulated by samana vayu. The annam pachati function of saman vayu encompasses all variables that stimulate the agni for digestion and metabolism.

In the modern perspective, the enteric nervous system is found in the gastrointestinal tract, and it is found in the gut wall from the oesophagus to the anus. In the enteric nervous system, there are 100 million neurons. It is responsible for the control of gastrointestinal movement and secretion. There are two major networks of nerve fibres that innervate the GIT, intrinsic and extrinsic, and together they form the enteric nervous system. The intrinsic innervation is divided into two plexuses. Meissner's plexus is found between the circular muscle and the mucosa in the submucosal region and sensory in function, whereas the Auerbach's plexus is found between the longitudinal and circular muscle layers of the digestive system and sensory in nature.

The extrinsic innervation is under the autonomic nervous control i.e., parasympathetic and sympathetic nerve fibres. Parasympathetic nerves release acetylcholine at their endings and produce contraction of GIT musculature. Stimulation of parasympathetic nerves to GIT produce increase motility and tone, relaxation of sphincters and increased secretion from the stomach. Sympathetic nerves to GIT produce decrease motility and tone, contraction of sphincters and inhibition of secretion from the stomach ${ }^{(8)}$

There are different juices and enzymes in our digestive system which helps in the digestion process for example pepsin enzyme which helps to digest protein, gastric juice main function is to inactivate swallowed microorganisms. Pancreatic juice Digestion of protein, carbohydrate and fat. Secretin enzyme that Stimulates pepsin secretion, pancreatic bicarbonate secretion, biliary bicarbonate secretion and inhibits gastric acid secretion. Pepsinogen enzyme that converts into pepsin for protein digestion etc.

3) ANNAM VIVECHAYATI - After the digestion of food it separated in essence and waste product in the grahani (small intestine). And the absorption of essential nutrients from food, water, minerals, and other sources. The watery component of the chyme is absorbed through the osmosis mechanism. Sodium is absorbed through active transport. Sodium-glucose cotransporter is responsible for glucose absorption, sodium amino acid cotransporter is responsible for protein absorption, and parathyroid hormone is responsible for calcium absorption. In a dehydrated person, aldosterone helps in sodium retention and corresponding chloride ion and water retention. ${ }^{(9)}$ In Ayurveda, samana vayu is responsible for all of these functions.

4) MUNCHATI - The term munchan means expulsion. It refers to the evacuation of waste items such as faeces and urine and this action is performed by apan vayu. And apan vayu executes its function by the initiation of samana vayu.

After food is digested, samana vayu initiates the movement of the GIT tract, which transports all waste 
products (faeces and urine) to their channels. As a result, Samana vayu triggers both the defecation and micturition reflexes.

When the defecation process begins, two types of reflexes are observed. One is a local ENS-mediated intrinsic reflex in the rectal wall. When faeces enter the rectum, Peristalsis from the descending colon to the sigmoid and rectum is caused by sensory signals begun by the mesenteric plexus.
The parasympathetic nervous system triggers the other defecation reflex. The nerve endings in the rectum are stimulated after faeces enters the rectum, and the signal is sent to the spinal cord. These parasympathetic signals pass down the pelvic nerve, causing peristalsis to increase and the internal anal sphincter to relax. Defecation occurs when the external anal sphincter is actively loosened at the same moment ${ }^{(10)}$

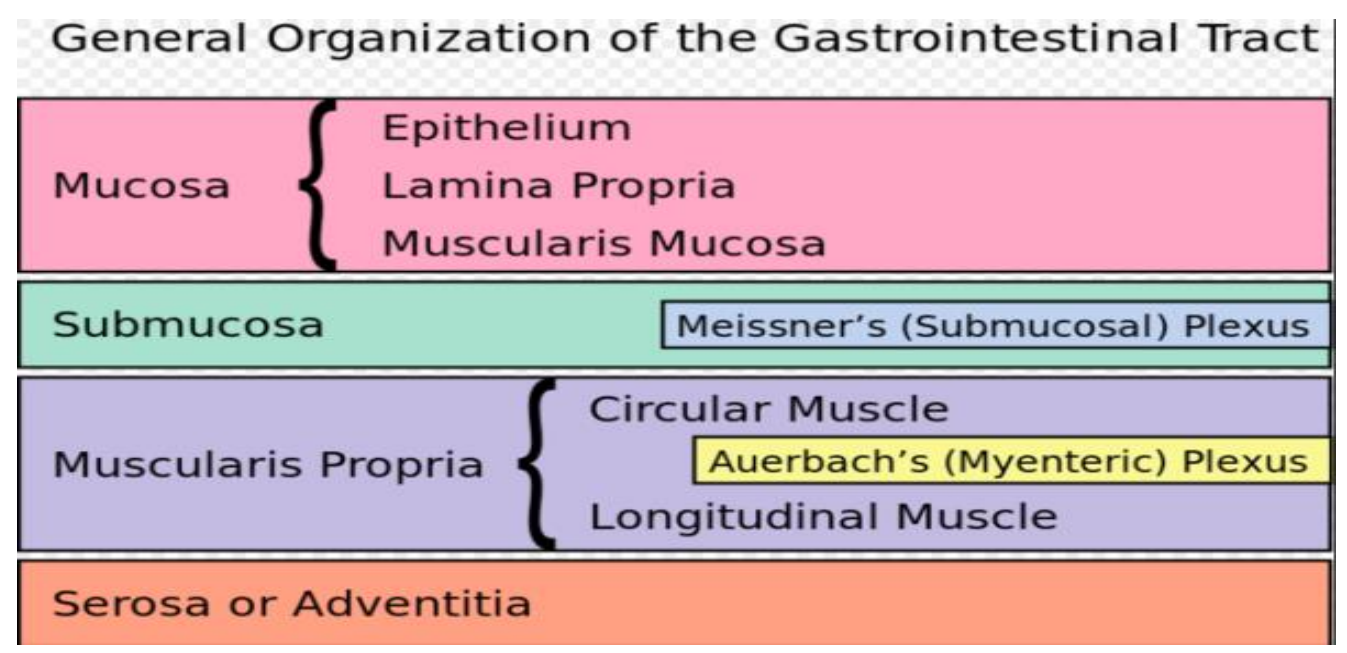

\section{ENTERIC NERVOUS SYSTEM}

The digestive system is controlled by the enteric nervous system (ENS), which is linked to the central nervous system (CNS) and sympathetic nervous system. The gastrointestinal system comprises a web of sensory neurons, motor neurons, and interneurons embedded in the wall that stretches from the bottom third of the oesophagus to the rectum. The submucosal and mesenteric plexuses of the gut wall contain the ENS neurons, which are organized into two layers. It generally connects with the CNS via the parasympathetic and sympathetic nervous systems.

(Sympathetic Nerves)- Preganglionic fibres arises from Between T5 and L2 of the lateral horn of

Spinal cord and terminate in celiac ganglia and mesenteric ganglia.

Then postganglionic fibres arise and distribute to the whole GIT.

(Para Sympathetic Nerves)- These fibres arise from cranial nerves and sacral nerves. In the mouth and sal- ivary glands, parasympathetic fibres arise from the facial nerve and glossopharyngeal nerve. Parasympathetic fibres of the Esophagus, stomach, small intestine and upper part of the large intestine arises from the $\mathrm{Va}$ gus nerve. Parasympathetic fibres of the Lower part of the large intestine and rectum arises from S2, S3, S4 segments.

\section{DIGESTIVE FIRE (Jatharagni) --}

As we all know, samana vayu is responsible for igniting the digestive fire. This activity is described in modern science as -

$>$ Saman vayu (vagus nerve) - stimulates digestive enzymes (pachak pitta) and digestion and metabolism occur

$>$ Various factors stimulate - inactive enzymes convert an active form of enzymes

$>$ After intake of food - stretch receptor stimulates a spate of secretion occurs 


\section{DISCUSSION}

All of our Acharyas explain Vata's superiority among the tridoshas. All processes are begun and directed by Vata, which is the natural pacemaker. It is the basic humoral element that regulates all of the body's functions. Samanavayu, one of the five types of vata, is found near Jathargani and stimulates digestion. Initiation of food ingestion, stimulation of digestive secretion, absorption of essence component, gastrointestinal motility, separation of the essence and waste product, and initiation of waste product removal through srotas are all benefits of Samana vayu. The combined functions of prana, vyana, apana vayu, and pachaka pitta perform these samana vayu duties.

The coordinative action of prana vayu aids in food intake to the oesophagus. The contraction and relaxation of the muscle, which is the function of vyana vayu, aids gastrointestinal motility. Because of the pachaka pitta's coordinative activity, it aids in food digestion. The coordinative action of apana vayu aids in the elimination of waste particles. The physiological functions of the 12th cranial nerve, which control the movement of hypoglossal muscle, swallowing Centre of medulla, 5th, 9th, 10th, 12th cranial nerve, peristaltic movement of GIT controlled by mesenteric plexus of ENS, can be compared with the functions of $\mathrm{Sa}$ mana vayu described by acharyas.

\section{CONCLUSION}

Different Acharyas have different functions for $\mathrm{Sa}$ mana vayu. It is primarily responsible for agni stimulation, which results in digestion, absorption, and separation of essence and waste. Vata dosha is involved in all types of systemic activity, therefore its functions might be interconnected with diverse structures at the cellular to organism level. It's linked to the enteric nervous system, as well as the autonomic nervous system's sympathetic and parasympathetic supply. It keeps the body in a state of equilibrium by activating and regulating the digestive system. As we all know that samana vayu gives strength to digestive fire and helps in digestion as well as different enzymes and digestive juices help in the Digestion process which is under the control of the enteric nervous system. For the betterment of mankind, more research is required to assess all other Vata doshas in detail.

\section{REFERENCES}

1. Shastri A, Doshadhaatumala kshyayavriddhi vigyaaniyaadhyaya, Ayurveda Tatwa Sandipika Hindi Commentary, Susruta Samhita, Varanasi Chaukhamba Sanskrit Sansthan, Edition-2010. page no-84

2. Pritam Moharana \& Rakesh Roushan: Effect of Prana and Vyana Vayu in NCDs W.S.R. To Cardiovascular System. International Ayurvedic Medical Journal 2018 \{cited May 2018\}

3. Pandey K, Chaturvedi G, Vatavyadhi Chikitsa Adhyaya, Charaka Samhita. Varanasi, India: Chaukambha Bharati Academy; 2015

4. Shastri A.D. Vatavyadhi Nidana Adhyaya, Ayurveda Tatwa Sandipika Hindi Commentary, Susruta Samhita, Varanasi Chaukhamba Sanskrit Sansthan; Edition2014.page no-296.

5. Tripathy B.N. Doshabhediya Adhyaya, Astanga Hridaya, Varanasi, India: Chaukambha Sanskrit Pratisthan; 2012

6. Gupta A.D. Doshabhediya Adhyaya, Astanga Sangraha, Varanasi, India: Chaukambha Krishnadas Academy; 2012

7. Hall. E, Guyton. C. Gastrointestinal physiology, Textbook of medical physiology, New Delhi (India), Elsevier; 2006, pg no. 776

8. Prof. A.K. Jain, textbook of physiology volume 1, 2008 pg no. 203.

9. Hall. E, Guyton. C. Gastrointestinal physiology, Textbook of medical physiology, New Delhi (India), Elsevier; 2006, pg no. 816

10. Hall. E, Guyton. C. Gastrointestinal physiology, Textbook of medical physiology, New Delhi (India), Elsevier; 2006 pg no. 789

\section{Source of Support: Nil Conflict of Interest: None Declared}

How to cite this URL: Neha Sajwan et al: A Review Article On The Physiological Importance Of Samana Va-Yu In Relation To The Enteric Nervous System. International Ayurvedic Medical Journal \{online\} 2021 \{cited December 2021\} Available from: http://www.iamj.in/posts/images/upload/3108_3112.pdf 